\title{
The New Strategy of Nike Corporate Communication in Efforts to Build a New Corporate Image
}

\author{
http://dx.doi.org/10.25008/jkiski.v6i2.549 \\ Dani Fadillah $^{1 *}$ Dong Hao², Bai Long ${ }^{3}$ \\ ${ }^{1}$ Universitas Ahmad Dahlan, Jl. Kapas, Semaki, Yogyakarta 55166 - Indonesia \\ ${ }^{2,3}$ Nanjing Normal University, 122 Ninghai Rd, Gulou, Nanjing, Jiangsu - China \\ ${ }^{*}$ Corresponding author: dani.fadillah@,comm.uad.ac.id
}

Submitted: August 12, 2021, Revised: September 20, 2021, Accepted: December 12, 2021

Accredited by Kemristekdikti No. 28/E/KPT/2019

\begin{abstract}
This study aims to examine the uniqueness of the corporate communication carried out by Nike when the well-known brand competes to sign a contract with athletes who reach their peak performance to promote its apparel. However, Nike signs contracts with players when they are still rising stars and then leaves them. Nike does something that well-known brands do not usually do. Normally, they compete to attract stars who are in their golden age. This research was conducted using a qualitative approach through case study research. The materials of this research were obtained by conducting a literature review, matters related to the Nike author's boredom collected from various sources, and reviewed using corporate communication logic. The results of this study indicate that Nike's steps are aimed at creating a new impression without leaving the old self-image.
\end{abstract}

Keywords: Strategy of Nike; corporate communication; football star; corporate immage; golde age

\section{Introduction}

Usually, the famous world-class apparel competes to get the exclusive contract with world-class athletes, where the world star players will wear their products to be seen by millions of eyes from all over the world. Thus, fans of sports around the globe will buy shoes, jersey and other sports equipment with the same brand as those charged by their idol athletes (Dickson \& Chang, 2015). An overall marketing communication strategy is done. At least renowned apparel always aims for football athletes from top five European leagues in Britain, Spain, Italy, Germany, and France to be used as their foremost ambassador (Rohde \& Breuer, 2016).

An interesting fact here is that until the end of 2020, Nike was the Biggest Share of
Player in Top Five Europe League, 53\% of Football players in the top five leagues of Europe wearing a Nike brand in their apparel, just then followed by Adidas (36\%) and Puma (7\%), while the rest wore Apparel like Mizuno, Lotto, Umbro and others (Statista Research Department, 2020). Even though if we look at history, all this time Adidas and Puma are more dominating the world football market, while Nike can be said to be late to join the Apparel in world competition for football sports. Since it was first established in the United States it focused more on basketball sports, Himngga, in the end, They tried to expand to Europe in the 1990s (Kolb, 2018).

When entering the European market, Nike immediately made a breakthrough by hooking star players like Romario, Eric 
Cantona, and Edgar Davids. And Nike's biggest deal was when they won the contract competition with the Youth Brazilian players in 1994. They became the FIFA world champion in 2002; after that, Nike continued to strengthen its positioning by signing contracts with famous football stars (NIKE.inc, 2014).

But at that time, Nike was still lagging behind Adidas, which was more superior and had a relationship with various players and clubs because of the preliminary playing in top five leagues of Europe. It was pretty heavy for Nike to compete with Adidas at that time, especially in the German League and the French League (Thomasson, 2016). Adidas has had a particular contract with Public darling German stars such as Miroslav Klose, Ballack, Oliver Kahn, Schweinsteiger, Lahm, and Muller.

So, how can now Nike master the European and world football market in a relatively short time? That's because Nike makes a breakthrough by not only aiming at The Best Player but also the Most Players as its brand ambassadors; this makes Nike more often appear in the public because the players are sorry for wearing a Nike logo on a variety of opportunities in the field and outside the area. Until now, the athlete who becomes the mainstay of Nike to dominate the world of sports, especially football, is Cristiano Ronaldo (Jennen, 2020). Along with the dip of Nike's time, they had to find a new soccer player to become the successor of Cristiano Ronaldo. So far, the name that has always appeared was Neymar, not only because he was a player with talent and a series of titles, but also because Nike had sponsored him since the player Still 13 years old (Surrey, 2015).

But who suspected, at the end of 2020 , Nike let Neymar go to belong to Puma (soccerbible, 2020). There is some speculation why Nike let Neymar go. Rumors have it that Neymar asks for a more significant pay to the issue that Neymar doesn't want to be under the shadows of Cristiano Ronaldo. For the first issue, it can still be debated, but for the second issue it is very unlikely because so far, it was reported that Neymar's bathing was not Ronaldo Malik Messi. He had left Barcelona (Burton, 2018).

Then there was also news that Neymar did not prove himself as the world's best player by never winning individual appreciation, such as Cristiano Ronaldo and Messi. Still, this assumption was raw because, in the same year, Nike turned out also to release Robert Lewandowski, who had just won awards for FIFA Player of the Year in 2020 on Puma (FootyHeadlines, 2020a). Lastly, Neymar is old and too glamorous and seems to have no concern for social issues that can partially increase Nike's positive image. However, this information finally only sets speculation because Raheem Sterling, who is younger than Neymar and is famous for his concern in eradicating racism, was also bound to his contract with Nike and now has signed a contract with New Balance, even though the Manchester City star has just extended his contract with Nike(Booker, 2020).

With the contracts of world-class players who are in the golden age such as Neymar, Lewandowski, Raheem Sterling, and more than 40 other star players from the top European leagues only in six months, of course, being an interesting question, the image is like what is Wants to be achieved by Nike at this time (FootyHeadlines, 2020b). When the other famous apparel competed to get star players to increase the selling value and positive image of their products, why Nike so quickly released the star players into 2021.

\section{Theoretical Framework}

Communication of the company or commonly called Corporate Communication is usually carried out by a company so that it can know and study the specifications of the products offered by the company, where the public, who is the target of the company's market, has strong confidence to use, own, and love the products offered (Bowen, 2019). Knowing the product specifications provided, doubts that are in the minds of the target market to use will thin even disappear; the target market will feel confident that the products offered will support their appearance and performance. At this level, in the review of corporate communication, the company has succeeded in convincing the target market that the product is the best offer ever given.

Then the next level of corporate communication is a sense of NGI; the feeling of wanting is divided into two groups. First, the feeling of having to have in full-sense, it can be interpreted that when trying it, the product used by the target market is a prototype or maybe just the item he can use, but it's not his asset (rented goods or loan). Therefore, the target market 
doesn't. It is limited to just wanting to be able to use but also scoop the property of the product entirely that they can use according to their needs anytime and anywhere without worrying about if there is damage or defect in the product. Second, the sense of wanting to have other products supporting the main products they used. For example, when a target market affects the form of shoes, then at that moment, they want to have socks as a supporting product.

The last level is to love products and brands. This is the highest level of the achievement of corporate communication. At this level, the development and brand of the company concerned have become opium that cannot be abandoned. There is unrest and another discomfort that will appear if the product or brand concerned is not used or not owned by the target market. It's not easy to reach this target because it's considered not just about how to market but also about building an image.

Talking about the image, it's a good idea to look for a moment what Kotler has ever conveyed; he once said that the image is a set of trust and ideas that make someone interested in particular objects (Kotler, 2012). At the same time, Vanhamme et al. have noted that the image is a feeling raised when someone knows a sure thing (Vanhamme et al., 2012). From what Kotler and Vanhamme et al. have expressed, we can come to the general conclusion that the image is a perception that wakes up and is stored in someone's mind so that it raises interest in a particular object.

Furthermore, Frank Jefkins once classified the image into four types, those are The Mirror Image which in the first type can be explained how the company's management, in this case, Nike, can feel how the community looks at the company; The Current Image, which can be explained how the community looks at Nike at this time, does not rule out the possibility of what the current image is contrary to The Mirror Image; The Wish Image which explains how the image achievement is expected to be achieved by the company; The multiple images, several individuals or representatives of companies that emit similar images are by what is dreamed of by the company so that a collective movement that makes public believe that the image is the face of the company (Jefkins, 2018).

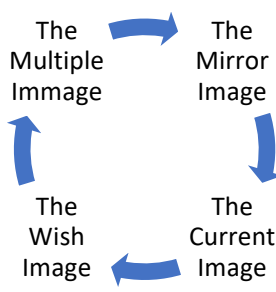

Figure 1. Image formation pattern by Frank Jefkins

From what is delivered by Jefkins above, we can conclude that image is something that can be formed, even in business logic image is something that must be created because it cannot just appear; there are several dimensions that the company must do to get a specific idea as to what has been delivered above. And to build the image is not enough to achieve it by trying once. Evaluation process must continue to be carried out within a certain period of time by re-referring to the steps Jefkins has classified for each dimension.

As a cover of this introduction, the author wanted to say that the unusual thing carried out by Nike in its corporate communication certainly intrigued to be explored further. This research has the potential to lend support to the birth of a new strategy in the world of corporate communication. During decades of corporate communication strategies learned by touch, scientists did not experience significant developments. Everything still uses classical logic with a formula that has no change at all. For example, if you want to introduce a product to the audience, pick up a famous figure to become a brand ambassador. It is always taught from generation to generation in the communication academic discussion room anytime; we have experienced the arrogance in thinking even though the scholarly communications world is not a doctrine, but ideas that must continue to develop even though they are sometimes out of the box.

The 4.0 era did make the emergence of several discoveries in corporate communications as research entitled Corporate Communication in the Industrial Era 4.0 (Purwandini \& Irwansyah, 2018), Media Sosial dan Perkembangan Komunikasi Korporat (Juwita, 2017), and Model Komunikasi Korporat Sari Ater Hotel \&amp; Resort dalam Menghadapi Revolusi Industri 4.0 (Ruliana et al., 2019). The manuscripts will only talk about using technology when conducting corporate communication; no one offers a new idea to 
incorporate communicators. In short, the latest technology, but the concept is still ancient.

\section{Material and Methodology}

The approach carried out in this study is qualitative, while this type of research is a case study. Case studies are a method in social science. A research that uses this method is carried out with a deep longitudinal examination of a state or events referred to as the case by using systematic ways to make observations (Rachmat Kriyantono, 2014). The collection of information is followed by conducting analysis and reporting results. As a result, it will be obtained a deep understanding of why something happens and can be the basis for further research; case studies can produce and test hypotheses (Mulyana, 2002). Other opinions also said that case studies are a research strategy, empirical review that investigates a symptom in the real-life background. This strategy can include quantitative evidence that leans on various previous sources and developments from theoretical propositions (Neuman, 2016). Case studies can use proof of both quantitative and qualitative. Research with a single subject provides a statistical framework for inference from quantitative case studies data.

The case study in this study was the phenomenon of the release of the famous football star contracts in Europe by renowned apparel, Nike. This case is considered essential to raise because Nike as a sports company does something that many of its competitors unusually do. The descriptive method is carried out to describe the findings obtained in the delivery of data so that the reader can clearly understand the problem in the discussion.

Data was collected by conducting an indepth review of documents that support this research; it can be news to be the results of other related researches. On several different occasions, this technique is also familiarly called Library Studies (Gupta et al., 2019). Because the approach in this study is qualitative, the data analysis technique used is a discourse analysis technique; the author tries to explore further and understand in-depth if what underlies a phenomenon can occur, in this case, the termination of the Bintan player contract by Nike ahead of New Year 2021.

The discourse does not appear by itself; the discourse is often formed by the maker of the discourse, the process of creating the discourse is called reality construction (Brock, 2018), from this process, something that will appear is called the text (discourse in the form of opinion, features, and Other manuscripts), Talks (in the form of voice recordings, talking, speech and so on), ACT (discourse in actions such as films, videos, plays drama and so on), and artifact (discourse in explicit form, fashion and so on). These things will be sailing continuously because each has a vital role in forming a discourse. Every process, text, talk, and artifact is influenced by internal and external factors. In the context of corporate communication, internal factors that affect these four things can change the organization's ideology or vision and mission. While external factors can be due to the company's sponsors or varying market share or company audiences that necessiate the company to make a significant overhaul.

The discourse analysis process in this study can be described in figure 2. Long story short of this research will begin reviewing anything related to how Nike's objective conditions, then try to find the reality construction process carried out by Nike in its corporate communication by appealing to the internal and external factors that influence itstunning that the framing strategy and priming technique will be reviewed when Nike carries out the reality construction process. 


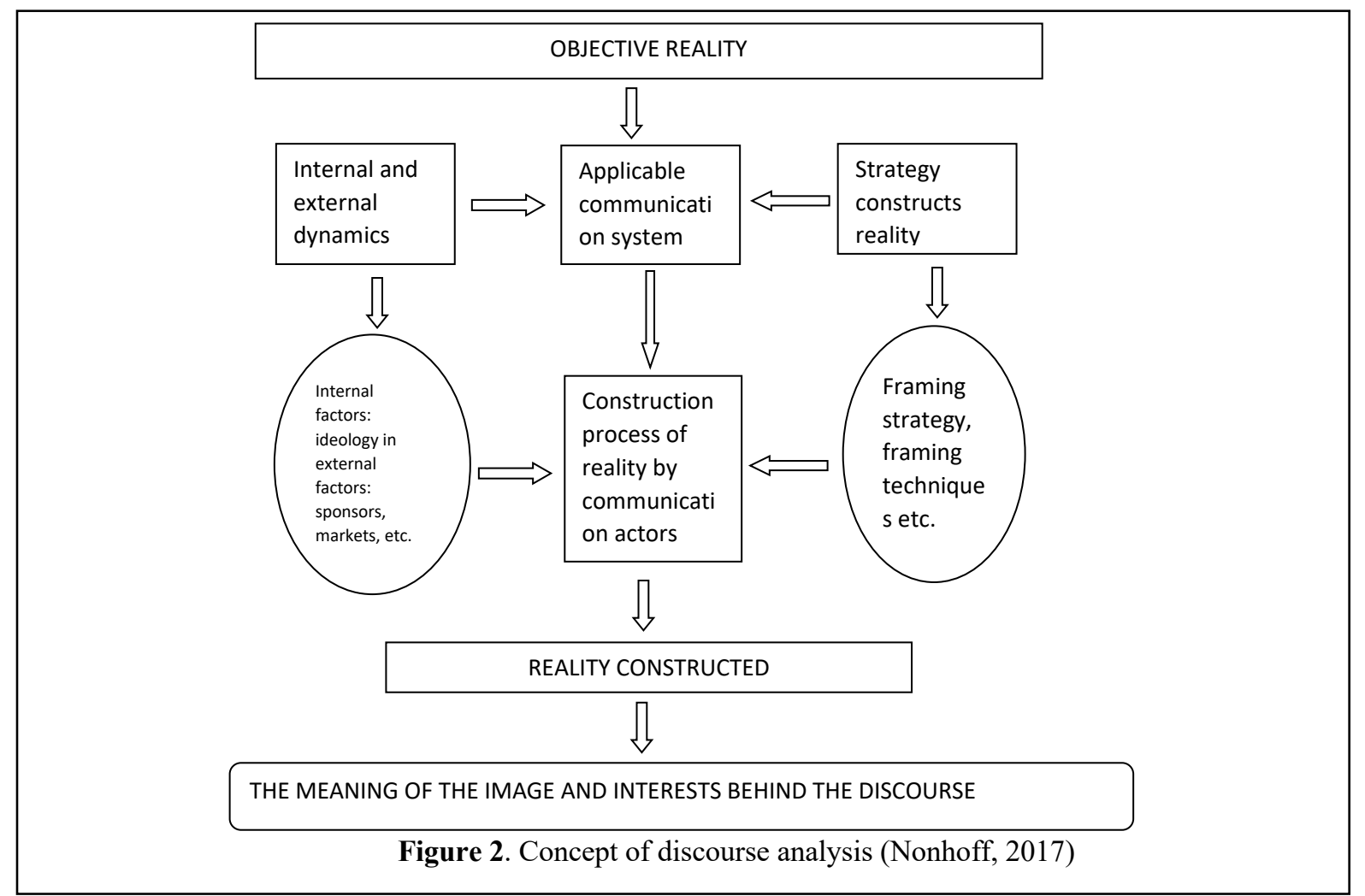

\section{Result and Discussion}

Based on the information that authorizes, the release of star players in the golden age by Nike is not something that has been done without careful planning; there are patterns built to get specific images by Nike. How is the way in question, and what is the image you want to go? We will discuss it in stages as follow.

The Covid-19 pandemic has brought about tough time to the sports industry, including football; this pandemic caused various significant events to be cancelled or postponed, including Summer Olympics 2020, Euro 2020, FIFA World Cup U20, and more than 40 other sports events (Sawitri, 2020). This prompted apparel throughout the world, especially apparel sports to try hard to rearrange to make savings while still maintaining and building a good image for their company (Barry, 2021).

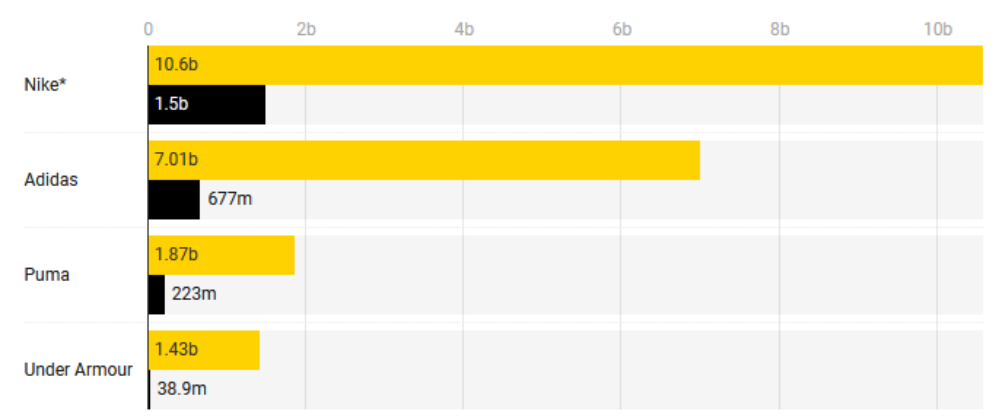

Figure 3. Financial Performance Apparel Sports World Before and at Pandemic (in USD) (Wong, 2020)

Realizing this, Nike took a quick step to finish the contract with a world-class player who was considered burdensome to the company's finances in this difficult time. It did not stop there, Nike still thought of how even though it had lost several well-known Stars who became its brand ambassadors, its image as world-class heavenly apparel remained awake.

As a result, Nike immediately signed a contract with a talented young figure, Erling 
Haale, which Borussia Dortmund had just recruited to play in the German League. Instead of playing games, Haaleland was immediately used to promote The Nike Dream Speed Boots and made Golden Nike Boots Special Edition Erling Haaland. Nike's brave steps can be ignored. They dare to release Robert Lewandowski, the best striker in the world, to give a place for the best striker Erling Haaland in the future.

Not only stopping in Haaleland, Nike also contacted the young Star of Paris Saint Germain F.C, Kylian Mbappe. The contract with Mbappe is not without reason. Compared to other young stars, Mbappe who is considered the best has a sense of memorabilia, with Cristiano Ronaldo as the biggest Nike Ambassador brand today. Mbappe contract value is much cheaper than that of PSG teammate Neymar who does not have a sense of memorabilia with Cristiano Ronaldo.

Raheem Sterling's departure was also replaced with Manchester United's young Star Marcus Rashford, who was also famous for the world of political spokesmen like Sterling. If Sterling often voiced loudly to fight racism, Rashford is renowned as an outspoken figure communicating food sharing movements for areas affected by the famine. This decision by Nike is considered the best decision by Nike; the value of Rashford's contract is cheaper than Sterling's; Rashford is also a figure affiliated to the humanist movement such as Sterling. And the added value possessed by Rashford is that he raised the issue of hunger that is purely neutral and can be accepted by anyone. At the same time, the anti-racism issue that is often voiced by Sterling is prone to political conflicts, so it is not too safe to maintain its Good brand. Besides the characters, several names like Sancho, Ansu Fati, Kal Havertz, Frankie de Jong, and a series of other talented young stars are still 20 years and below. Technically, Nike has prepared the future of its ambassador brand.

This time it withdraws the contract between apparel and the player which usually lasts for several years or long-term investment; this is because the sports industry is foresight. Apparel predicts which players will have a bright future in the next five years, considering that generally the age of 25 years is the age of the football player if the player continues to grow up to the age of 25 years, so it is likely to be a big star, but if until the age of its deeds is still mediocre, Hamper can be ascertained to be an ordinary player.

Therefore, Nike's decision to release their golden stars was not wrong because the players were 25 years and above, but their appearance had stagnated and would even decrease, it was not good for the sponsor's image. Meanwhile, the step of Nike to recruit the Raising Star aged 20 years and below is the right step because their appearance will tend to increase, and will have a good effect on the sponsor's image.

It is not difficult for Nike to promote the big name and positive image by relying on young talented players in their new appearances because in its more than one decade of experience in handling names such as Neymar and Lewandowski, Nike already has all sales data on consumers and the ability to estimate its brand values in the future.

Next, by using Jefkins' logic of thinking, we can express the steps taken by Nike as follows:

The Mirror image. Nike realized that it was the number one sports apparel globally; Brand Value which reached 34.793 million USD in 2020, was undisputed evidence. Emotional branding techniques carried out by carrying themes Heroism to Inspire succeeded in building customer loyalty throughout the world (Lin, 2020). This value is far above that of its rival, Adidas, which is only 16,461 million USD.

The Current Image. Nike is also known for high-quality sports products that offer not only comfort but also style. Nike products are suitable to be worn by people aged 15-45 with various products that can not only be used to exercise, for example, Nike Blazers (Eberoi, 2020).

The Wish Image. By looking at the strategic steps carried out by Nike, the new image it hopes seems to be ascertained not to change the image that has been built so far, but to perfect the existing image. By hooking the Erling Haaland, Nike wants to develop the impression as the Talent Maker, recruiting Rashford, a spokesperson on social issues that Nike wishes to get the image as a positive social impact.

The Multiple Image. Now we are just waiting for how Nike concocts the young ambassador brand it has recruited if the young talents it chooses can be consistent in the game above the green field and consistently maintain its positive image, so at least in the next five 
years, the image of Nike will increase and have a good effect on its brand values.

But Nike still must be careful because the young players they contracts do indeed show extraordinary individual talents but have not yet been among those who have succeeded in obtaining prestigious individual titles. As well as young players do not close their unstable and lose their consistency while being off the field. Nike management must always take the news of their young athletes, by often giving warnings through the player's agent, and immediately evaluating them if there are signs that they will endanger its positive image.

Based on the schedule above, the logic of discourse analysis stated in this research method can be concluded: First, Objective Reality Nike is a trademark used by big and well-known players; only big stars are worth using and sponsored by Nike. Here Nike transformed into a throne used explicitly by those who were "nobles," if the athlete had not reached the level, they had not been feasible to be sponsored by Nike. Nike is in the sky that cannot be acquired by the athlete that is still a mediocre status.

Both external and internal situations affect the Nike Communication System so far. Externally, the Covid-19 pandemic spread throughout the world forces the termination of various sports competitions around the globe. This resulted in Nike as a sports apparel losing land to show off and promote its products. Internally, due to the cessation of Braga's competition, Nike's finance is unstable.
Although according to the calculation, Nike's finance is still relatively safe, revenue decreases cannot be avoided, especially because Nike must spend money for free on the Super Star athletes who become Nike's Brand Ambassador. For this reason, it must immediately take strategic steps so that expenses can be suppressed, but the image of Nike as a top-class product is maintained. So it terminated its contract with the star players and begins recruiting the Rising Star.

Fourth, in controlling this reality, Nike slams the steering wheel from a company that becomes a style and mandatory system of upscale players into products that give birth to future stars. The upper-class star players released by Nike are interpreted as Nike who has finished guiding them, and it's time for Nike to teach the athletes who are currently advocating replacing the position of the big stars in the future. Fifth, in this section, it can be concluded that Nike's interests in releasing its star players and recruiting Star's rising are to save the company's finances that are wasted because it has to pay sponsorships on the star players who still have the contract, besides Nike's image as The apparel of sports belonging to the stars can remain awake by removing a much cheaper contract. Even Nike gets an image bonus, namely as an Olag company that supports the emergence of new stars. Simply, the concept of discourse analysis of Nike corporate communication can be seen in Table 1.

Tabel 1. Concept of discourse analysis by Nike

\begin{tabular}{l|l} 
Objective reality & $\begin{array}{l}\text { 1. Nike is an upscale athlete apparel } \\
\text { 2. An athlete must smell the maximum appearance to become a Nike brand }\end{array}$ \\
\hline $\begin{array}{l}\text { Applicable } \\
\text { communication } \\
\text { system }\end{array}$ & $\begin{array}{l}\text { 1. Nike always recruits upscale athletes to build the company's brand image. } \\
\text { 2. The costs incurred by Nike to take the top world-class players are very } \\
\text { large }\end{array}$ \\
\hline $\begin{array}{l}\text { Reality construction } \\
\text { process }\end{array}$ & $\begin{array}{l}\text { 1. Nike releases the contract of upscale players who have become a company } \\
\text { icon }\end{array}$ \\
\hline Reality constructed & $\begin{array}{l}\text { Nike signs contracts with young players whose contract value is cheaper to } \\
\text { introduce product company }\end{array}$ \\
& $\begin{array}{l}\text { Nike is a sports apparel that supports the birth of new stars. } \\
\text { Nike is a company that cares for the development of talented young talents }\end{array}$
\end{tabular}

\section{Conclusions}

Nike's decision to let a series of class players such as Duna Perg go is more than just a financial business, but is a Nike strategy to form an image as a supporter of the new generation of future soccer players. Nike had planned this, but the Covid-19 pandemic prompted it to accelerate the execution of the 
plan as can be seen, for example, from the case of Neymar, who was released in 2020 even though his contract was still two years left. All have been planned carefully, so even though the old star who became the Nike Brand Ambassador joined the rival apparel, it was not a problem; the threat to Nike was minimal even perhaps it tended not to exist.

The real of the star players was a corporate communication effort carried out by Nike to form a new corporate image. If so far Nike is taken as a sports apparel that is the fashion of the star players, then this time Nike wants to be known as a sports apparel which has accompanied a career trip of the Rising Star; if so far Nike is known as an exclusive company just approaching the big star, then at this moment Nike wants to be known as an inclusive company near the young talents, even Nike is the one who supports the talent to appear and continue to be maintained.

\section{References}

Barry, L. (2021). How Corona Virus is Impacting the Global Apparel Industry. Just-Style. https://www.juststyle.com/news/timeline-howcoronavirus-is-impacting-the-globalapparel-industry-free-toread_id138313.aspx

Booker, A. (2020). Raheem Sterling could be close to an official announcement with major football brand. FanNation. https://www.si.com/soccer/manchesterci ty/news/raheem-sterling-could-be-closeto-an-official-announcement-withmajor-football-brand

Bowen, S. A. (2019). Corporate communication. In An Integrated Approach to Communication Theory and Research, Third Edition. https://doi.org/10.4324/978020371075334

Brock, A. (2018). Critical technocultural discourse analysis. New Media and Society. https://doi.org/10.1177/1461444816677 532

Burton, C. (2018). "Neymar had to step out of Messi's shadow" - Barcelona exit a good thing, says Dani Alves. Goal.Com. https://www.goal.com/en/news/neymar- had-to-step-out-of-messis-shadow-

barcelona-exit-

a/f016hz4oapfwlikumv44s0jgp

Dickson, M. A., \& Chang, R. K. (2015). Apparel manufacturers' path toworld class corporate social responsibility: Perspectives of CSR professionals. In Sustainable Fashion Supply Chain Management: From Sourcing to Retailing. https://doi.org/10.1007/978-3319-12703-3_6

Eberoi, M. (2020). Nike's Target Markets: Everything You Need to Know. Market Realist.

https://marketrealist.com/2019/10/nikestarget-markets-everything-you-need-toknow/

FootyHeadlines. (2020a). Lewandowski to Join Puma, Wears 2021 Future Z Boots. Footy Headlines. https://www.footyheadlines.com/2020/1 0/lewandowski-to-join-puma.html

FootyHeadlines. (2020b). Nike Has Lost More Than 40 Important Players In Past 6 Months - Updated. Footy Headlines. https://www.footyheadlines.com/2021/0 1/nike-has-lost-around-20important.html

Gupta, D. K., Gupta, B. M., \& Gupta, R. (2019). Global library marketing research. Library Management. https://doi.org/10.1108/1m-05-20180039

Jefkins, F. (2018). Definisi Dan Kekhususan Public Relations. In Public Relations.

Jennen, B. (2020). Cristiano Ronaldo Gets 162 Million Euros From Nike Deal: Spiegel. Bloomberg. https://sportskhabri.com/cristianoronaldos-brand-partners-in-2020/

Juwita, R. (2017). Media Sosial dan Perkembangan Komunikasi Korporat. Jurnal Penelitian Komunikasi, 20(1), 47-60. https://doi.org/10.20422/jpk.v20i1.136

Kolb, R. W. (2018). Nike, Inc. In The SAGE Encyclopedia of Business Ethics and Society. https://doi.org/10.4135/9781483381503. n850 
Kotler, P. (2012). Kotler On Marketing. In Kotler On Marketing.

Lin, X. (2020). The Brand Equity of Nike, what makes it the best sports brand ever? Medium.Com.

https://medium.com/@xlin6/the-brandequity-of-nike-what-makes-it-the-bestsports-brand-ever-561a24fd296e

Mulyana, D. (2002). Metode Penelitian Kualitatif. Rosdakarya.

Neuman, W. L. (2016). Metodologi Penelitian Sosial: Pendekatan Kualitatif dan Kuantitatif. PT. Indeks.

NIKE.inc. (2014). The Definitive History of Nike in Football. NIKE News. https://news.nike.com/news/thedefinitive-history-of-nike-in-football

Nonhoff, M. (2017). Discourse analysis as critique. Palgrave Communications, 3(1), 17074. https://doi.org/10.1057/palcomms.2017. 74

Purwandini, D. A., \& Irwansyah, I. (2018). Komunikasi Korporasi pada Era Industri 4.0. Jurnal Ilmu Sosial, 17(1), 53. https://doi.org/10.14710/jis.17.1.2018.53 $-63$

Rachmat Kriyantono, P. D. (2014). Teknik Praktis Riset Komunikasi (1st ed.). Kencana.

Rohde, M., \& Breuer, C. (2016). Europe's Elite Football: Financial Growth, Sporting Success, Transfer Investment, and Private Majority Investors. International Journal of Financial Studies. https://doi.org/10.3390/ijfs4020012

Ruliana, P., Lestari, P., \& Andrini, S. (2019). Model Komunikasi Korporat Sari Ater Hotel \&amp; Resort Dalam Menghadapi Revolusi Industri 4.0. Jurnal ASPIKOM, 4(1),

60. https://doi.org/10.24329/aspikom.v4i1.5 35

Sawitri, Y. M. (2020). Lebih dari 40 Event Olahraga Dunia Terdampak Virus Corona, Ditunda atau Dibatalkan. Bola.Com.

https://www.bola.com/ragam/read/4192 089/lebih-dari-40-event-olahraga-duniaterdampak-virus-corona-ditunda-ataudibatalkan

soccerbible. (2020). Is Neymar The Missing Piece In PUMA's Puzzle? Soccer Bible. https://www.soccerbible.com/news/2020 /09/is-neymar-the-missing-piece-inpumas-puzzle/

Statista Research Department. (2020). Nike Statistics \& Facts. Statista. https://www.statista.com/topics/1243/ni ke/

Surrey, M. (2015). Neymar Set To Overtake Ronaldo, Become Face of Nike. The18.Com.

https://the18.com/en/news/neymar-nikeposter-boy-takes-over-for-ronaldo

Thomasson, E. (2016). New Adidas CEO sets off in pursuit of Nike. Reuters Thomson. https://www.reuters.com/article/usadidas-moves-ceo-idUSKCN11Z1DA

Vanhamme, J., Lindgreen, A., Reast, J., \& van Popering, N. (2012). To Do Well by Doing Good: Improving Corporate Image Through Cause-Related Marketing. Journal of Business Ethics. https://doi.org/10.1007/s10551-0111134-0

Wong, M. (2020). Sizing up the sportswear giants in 2020. SportsPro. https://www.sportspromedia.com/analys is/nike-adidas-puma-under-armoursportswear-profit-loss-annual-reports2020 